\title{
O nordon
}

Pohjoismaiden ministerineuvosto

\section{Toimintasuunnitelma ja budjetti 2015 - tiivistelmä}




\section{Sisällysluettelo}

$5 \quad$ Toimintasuunnitelma ja budjetti 2015

5 Uusi pohjoismainen budjetti

6 Budjetin kokonaiskehys ja sektorikohtainen jakauma

9 Vuoden 2015 budjetin päälinjat

9 Ministerineuvostojen poliittiset painopisteet

10 Keskustelut Pohjoismaiden neuvoston kanssa vuoden 2015 budjetista

12 Budjetin tulot ja maiden maksuosuudet

13 Maiden ennustetut maksuosuudet kansallisina valuuttoina

14 Budjetin kehitys vuosina 2004-2015

15 Katsaus: Pohjoismaiden ministerineuvoston budjetti budjettikohdittain

22 Liite 1: Pohjoismaisten laitosten määrärahat kansallisina valuuttoina

23 Liite 2: Valuuttakurssit ja inflaatioprosentit 2015 
Pohjoismaiden ministerineuvosto

Toimintasuunnitelma ja budjetti 2015 - tiivistelmä

ISBN 978-92-893-4017-5 (PRINT)

ISBN 978-92-893-4018-2 (PDF)

http://dx.doi.org/10.6027/ANP2015-717

ANP 2015:717

(C) Pohjoismaiden ministerineuvosto 2015

Paino: Scanprint as

Painos: 100

Printed in Denmark

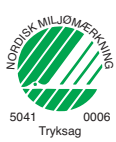

www.norden.org/fi/julkaisut
Pohjoismainen yhteistyö

Pohjoismainen yhteistyö on yksi maailman laajimpia alueellisia yhteistyömuotoja. Yhteistyön piiriin kuuluvat Islanti, Norja, Ruotsi, Suomi ja Tanska sekä Ahvenanmaa, Färsaaret ja Grönlanti.

Pohjoismaista yhteistyötä tehdään politiikan, talouden ja kulttuurin aloilla tärkeänä osana eurooppalaista ja kansainvälistä yhteistyötä. Pohjoismaisen yhteisön tavoitteena on vahva Pohjola vahvassa Euroopassa.

Pohjoismainen yhteistyö pyrkii vahvistamaan pohjoismaisia ja alueellisia etuja ja arvoja globaalissa maailmassa. Maiden yhteiset arvot lujittavat osaltaan Pohjolan asemaa yhtenä maailman innovatiivisimmista ja kilpailukykyisimmistä alueista.

Pohjoismaiden ministerineuvosto

Ved Stranden 18

DK-1061 København K

Puhelin (+45) 33960200

www.norden.org 


\section{Toimintasuunnitelma ja budjetti 2015}

\section{Uusi pohjoismainen budjetti}

Vuodesta 2015 tulee tärkeä, koska sen aikana toteutetaan yhteistyöministerien kesäkuussa 2014 hyväksymä yhteistyön uudistus. Uudistuksen tavoitteena vahvistaa ministeritason pohjoismaista yhteistyötä, tehostaa sihteeristön toimintaa, lisätä ministerineuvoston hanke- ja ohjelmatoiminnasta saatavaa pohjoismaista hyötyä sekä parantaa pohjoismaisten laitosten ohjausta. Uudistuksen tärkeänä osana on vuoden 2015 budjettikirjan uudistaminen. Budjetin jaottelua ja rakennetta on muutettu merkittävästi, millä pyritään selkeyttämään tavoitteita ja tulosten seurantaa. Lisäksi on pyritty kauttaaltaan parantamaan asiakirjan ymmärrettävyyttä ja käytettävyyttä. Budjettiuudistuksen toisena tärkeänä osana on budjetin painopistealueita ja päälinjoja koskevan vuoropuhelun vahvistaminen Pohjoismaiden neuvoston kanssa.

Vuoden 2015 budjetti on laadittu yhteistyöministerien hyväksymien kehysten ja suuntaviivojen pohjalta, ja se perustuu eri sektoreilta saatuihin aloitteisiin. Budjetin profiilin ja painopistealueiden perustana on niin ikään yhteistyöministerien vuonna 2014 hyväksymä visio rajattomasta, innovatiivisesta, näkyvästä ja ulospäin suuntautuneesta Pohjolasta. Budjettikehys on $2 \%$ pienempi kuin vuoden 2014 budjetissa. Leikkaus toteutetaan sektorikohtaisilla priorisoinneilla.

Pohjoismaiden ministerineuvoston vuoden 2015 budjetti mahdollistaa monia tärkeitä panostuksia kaikilla sektoreilla. Priorisointibudjetin käyttöä jatketaan niiden tavoitteiden pohjalta, joista sovittiin sen käyttöönoton yhteydessä vuonna 2013. Vuoden aikana jatketaan olennaisilta osin Ruotsin puheenjohtajakaudella vuonna 2013 sekä Islannin puheenjohtajakaudella vuonna 2014 aloitettuja panostuksia, minkä lisäksi toteutetaan vuoden 2015 puheenjohtajamaan Tanskan uusia aloitteita. Tanskan puheenjohtaja- kausi keskittyy kasvuun, hyvinvointiin, arvoihin ja siniseen Arktikseen. Priorisointibudjetti mahdollistaa myös muun muassa aiemmin käynnistettyjen Vihreä kasvu- ja Kestävä pohjoismainen hyvinvointi -panostusten jatkamisen.

Ruotsin entisen sosiaaliministerin Bo Könbergin johdolla on toteutettu suuri selvitystyö terveysalan pohjoismaisen yhteistyön mahdollisuuksista. Työtä koskeva raportti julkistettiin keväällä 2014. Vuoden 2015 budjetissa on osoitettu varoja selvitykseen perustuviin toimiin sekä uusiin vastaaviin strategiaselvityksiin. Työelämän ministerineuvosto (MR-A) on jo päättänyt teettää strategiaselvityksen työelämäalan pohjoismaisesta yhteistyöstä.

Vuoden aikana panostetaan entiseen tapaan naapurimaiden ja muiden toimijoiden kanssa tehtävään kansainväliseen yhteistyöhön. Vuoden erityisiin painopistealueisiin kuuluu Pohjoismaiden kansainvälinen profilointi ja asemointi, jota tehdään yhteistyöministerien vuonna 2014 hyväksymän strategian mukaisesti. Keskiössä on niin ikään rajaesteiden poistaminen, jonka tärkeänä toimijana on rajaesteneuvosto.

Budjettiprosessin aikana on käyty vuoropuhelua Pohjoismaiden neuvoston kanssa. Pohjoismaiden neuvoston ja Pohjoismaiden ministerineuvoston välisten budjettineuvottelujen tuloksena oli 18-kohtainen kompromissi. Kompromissi on sisällytetty budjettikirjaan sellaisenaan. Kompromissiin liittyviä sektoribudjetteja ja budjettikohtia tulee lukea kompromissin mukaisesti.

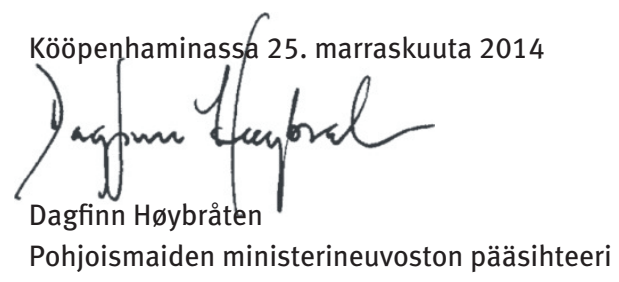




\section{Budjetin kokonaiskehys ja sektorikohtainen jakauma}

Pohjoismaiden ministerineuvoston vuoden 2015 kokonaismenokehys on 931782000 Tanskan kruunua, eli siihen on tehty 2 \%:n leikkaus vuoteen 2014 verrattuna (vuoden 2014 hinnoin). Tämä vastaa 19 miljoonan Tanskan kruunun säästöä.

Kehyksen erittely:

\begin{tabular}{lr}
\hline KOKONAISKEHYKSEN RAKENNE & $\begin{array}{r}\text { TUHATTA } \\
\text { TANSKAN } \\
\text { KRUUNUA }\end{array}$ \\
\hline Budjetti 2014 & 955215 \\
\hline $2 \%: n$ säästö & -19105 \\
\hline $\begin{array}{l}\text { Vuoden } 2015 \text { hyväksytty budjetti vuoden 2014 } \\
\text { hinnoin }\end{array}$ & 936110 \\
\hline $\begin{array}{l}\text { Vuoden } 2015 \text { hintatason mukainen inflaatio- } \\
\text { korjaus }\end{array}$ & 14636 \\
\hline $\begin{array}{l}\text { Valuuttakurssikorjaus } \\
\text { Yhteensä vuoden 2015 hinnoin }\end{array}$ & -18964 \\
\hline
\end{tabular}

Vuoden 2015 budjettikehykseen (vuoden 2014 hinnoin) lisätään liitteestä 2 ilmenevien kertoimien ja valuuttakurssien mukaisesti tehdyn inflaatio- ja valuuttakurssikorjauksen vaikutus, ja näin laskemalla saadaan Pohjoismaiden ministerineuvoston kokonaismenokehys vuodeksi 2015.
Vuoden 2015 budjetin inflaatiokorjaus on 14636000 Tanskan kruunua, eli korjausprosentti on keskimäärin 1,6 \%. Laitosten määrärahojen muunnos kansallisista valuutoista Tanskan kruunuiksi taas pienentää budjettia 18964000 Tanskan kruunua. Tällä ei kuitenkaan ole reaalista vaikutusta budjetin kokoon (ja maiden maksuosuuksiin) tai laitosten määrärahojen suuruuteen. Valuuttakursseja käytetään yksinomaan muunnettaessa sijaintimaan valuuttana maksettavia laitosten määrärahoja Tanskan kruunuiksi.

Seuraavalla sivulla on vuoden 2015 menokehyksen sektorikohtainen jakauma. 


\section{VUOSIEN 2015 JA 2014 BUDJETTIEN VERTAILU (käyvin hinnoin, tuhatta Tanskan kruunua)}

1 Yhteistyöministerit (MR-SAM)
a. Priorisointibudjetti
b. Kansainvälinen yhteistyö
i. Toimistojen osuus*
c. Pohjoismaiden ministerineuvoston yhteiset toiminnot ja sihteeristö
i. Sihteeristön osuus (ministerineuvoston sihteeristö)

2. Koulutus- ja tutkimusministerineuvosto (MR-U)

$\begin{array}{r}\text { Budjetti } \\ 2015 \\ \hline 255258 \\ \hline 74375 \\ 74320 \\ 21330 \\ \hline 106 \quad 563 \\ 77 \quad 560 \\ \hline\end{array}$
a. Yleiset tutkimus- ja koulutusaloitteet
b. Politiikan kehittäminen ym.
c. Liikkuvuus- ja verkosto-ohjelmat
d. Nordforsk (laitos)
e. Muu tutkimus

3. Sosiaali- ja terveyspolitiikan ministerineuvosto (MR-S)

228116

3680

15481

75735

111296

21924

i. Pohjoismaisen hyvinvointikeskuksen osuus (laitos)

4. Kulttuuriministerineuvosto (MR-K)

a. Yleiset kulttuuripanostukset

b. Lapset ja nuoret

c. Elokuva ja viestimet

i. NORDICOMin osuus (laitos)
d. Taideala
Pohjoismaisten kulttuuritalojen osuus (laitoksia)
e. Muut kulttuuripanostukset

\begin{tabular}{|c|c|c|c|}
\hline $\begin{array}{r}\text { Budjetti } \\
2015\end{array}$ & $\begin{array}{r}\text { Budjetti } \\
2014\end{array}$ & $+/-$ & $\begin{array}{r}\text { Erotus } \\
\%\end{array}$ \\
\hline 255258 & 256910 & -1652 & $-0,6 \%$ \\
\hline 74375 & 74768 & -393 & $-0,5 \%$ \\
\hline 74320 & 74780 & -460 & $-0,6 \%$ \\
\hline 21330 & 21077 & 253 & $1,2 \%$ \\
\hline 106563 & 107362 & -799 & $-0,7 \%$ \\
\hline 77560 & 78204 & -644 & $-0,8 \%$ \\
\hline 228116 & 238384 & -10268 & $-4,3 \%$ \\
\hline 3680 & 2939 & 741 & $25,2 \%$ \\
\hline 15481 & 17847 & -2366 & $-13,3 \%$ \\
\hline 75735 & 74616 & 1119 & $1,5 \%$ \\
\hline 111296 & 121382 & -10086 & $-8,3 \%$ \\
\hline 21924 & 21600 & 324 & $1,5 \%$ \\
\hline 38956 & 40293 & -1337 & $-3,3 \%$ \\
\hline 20335 & 21142 & -807 & $-3,8 \%$ \\
\hline 167143 & 167879 & -736 & $-0,4 \%$ \\
\hline 46284 & 46416 & -132 & $-0,3 \%$ \\
\hline 6036 & 6068 & -32 & $-0,5 \%$ \\
\hline 35062 & 37207 & -2145 & $-5,8 \%$ \\
\hline 3025 & 3144 & -119 & $-3,8 \%$ \\
\hline 76003 & 74486 & 1517 & $2,0 \%$ \\
\hline 42793 & 41767 & 1026 & $2,5 \%$ \\
\hline 3758 & 3702 & 56 & $1,5 \%$ \\
\hline 39769 & 41093 & -1324 & $-3,2 \%$ \\
\hline 6198 & 6106 & 92 & $1,5 \%$ \\
\hline 21204 & 21981 & -777 & $-3,5 \%$ \\
\hline 20016 & 20810 & -794 & $-3,8 \%$ \\
\hline 6500 & 7226 & -726 & $-10,0 \%$ \\
\hline 5867 & 5780 & 87 & $1,5 \%$ \\
\hline
\end{tabular}

5. Maa- ja metsätalous-, kalastus-, vesiviljely- ja elintarvikeasiain ministerineuvosto (MR-FJLS)
a. Kalastus
b. Maatalous
i. NordGenin osuus (laitos)
c. Elintarvikkeet
d. Metsätalous 
Jatkoa edelliseltä sivulta

VUOSIEN 2015 JA 2014 BUDJEITIEN VERTAILU (käyvin hinnoin, tuhatta Tanskan kruunua)

\begin{tabular}{|c|c|c|c|c|}
\hline & Budjetti & Budjetti & & Erotus \\
\hline & 2015 & 2014 & $+/-$ & $\%$ \\
\hline 6. Tasa-arvoasiain ministerineuvosto (MR-JÄM) & 8873 & 8919 & -46 & $-0,5 \%$ \\
\hline 7. Elinkeino-, energia- ja aluepolitiikan ministerineuvosto (MR-NER) & 132686 & 140438 & -7752 & $-5,5 \%$ \\
\hline a. Elinkeinopolitiikka & 89619 & 95991 & -6372 & $-6,6 \%$ \\
\hline i. Nordic Innovationin osuus (laitos) & 72471 & 79096 & -6625 & $-8,4 \%$ \\
\hline b. Energia & 10582 & 11163 & -581 & $-5,2 \%$ \\
\hline i. Pohjoismaisen energiantutkimuksen osuus (laitos) & 6452 & 6971 & -519 & $-7,4 \%$ \\
\hline c. Aluepolitiikka & 32485 & 33284 & -799 & $-2,4 \%$ \\
\hline i. Nordregion osuus (laitos) & 11254 & 11701 & -447 & $-3,8 \%$ \\
\hline 8. Ympäristöasiain ministerineuvosto (MR-M) & 44157 & 44392 & -235 & $-0,5 \%$ \\
\hline 9. Työelämän ministerineuvosto (MR-A) & 13632 & 13698 & -66 & $-0,5 \%$ \\
\hline i. NIVAn osuus (laitos) & 3370 & 3314 & 56 & $1,7 \%$ \\
\hline 10. Talous- ja rahapolitiikan ministerineuvosto (MR-FINANS) & 1810 & 1819 & -9 & $-0,5 \%$ \\
\hline 11. Oikeusyhteistyön ministerineuvosto (MR-LAG) & 1382 & 1390 & -8 & $-0,6 \%$ \\
\hline Pohjoismainen budjetti yhteensä & 931782 & 955215 & -23433 & $-2,5 \%$ \\
\hline
\end{tabular}

*Ministerineuvoston Viron-, Latvian-, Liettuan- ja Luoteis-Venäjän-toimistot

Kehysten jakautuminen eri budjettikohtiin Tanskan kruunuina ilmenee sivun 15 taulukosta. 


\section{Vuoden 2015 budjetin päälinjat}

Pohjoismaiden ministerineuvosto on Pohjoismaiden hallitusten virallinen yhteistyöfoorumi. Ministerineuvoston työtä säätelee Helsingin sopimus, jota muutettiin viimeksi vuonna 1995.

Päävastuu ministerineuvoston työn koordinoinnista on pohjoismaisilla yhteistyöministereillä (MR-SAM). Yhteistyöministerien ministerineuvoston lisäksi yhteistyötä toteutetaan kymmenessä alakohtaisessa ministerineuvostossa.

Pohjoismaiden ministerineuvoston puheenjohtajakausi kiertää Pohjoismaiden välillä. Vuoden 2015 alussa puheenjohtajuus siirtyy Islannilta Tanskalle.

Yhteistyöministerit ovat päättäneet, että vuoden 2015 pohjoismaista budjettia leikataan $2 \%$. Säästövaatimus jakautuu tasan alakohtaisten kehysten kesken. Priorisoinnit tehdään siten alakohtaisissa budjeteissa.

Kahden prosentin säästövaatimuksesta huolimatta vuonna 2015 jatketaan Pohjoismaiden ministerineuvoston Kestävä pohjoismainen hyvinvointi- ja Vihreä kasvu -panostuksia sekä Ruotsin ja Islannin puheenjohtajakausien priorisoituja panostuksia. Niiden lisäksi tulevat Tanskan vuoden 2015 puheenjohtajakauden panostukset.

Budjettiehdotus laaditaan alakohtaisten ministerineuvostojen esitysten pohjalta, ja priorisoinnit ja säästöt perustuvat niihin. Yhteistyöministerien budjettiehdotuksesta päätettiin syyskuussa 2014 pääsihteerin ehdotuksen sekä kansallisen lausuntokierroksen pohjalta. Lopullisen budjetin hyväksyivät lokakuussa yhteistyöministerit Pohjoismaiden neuvoston kanssa käytyjen keskustelujen jälkeen.

Seuraavassa kuvataan yleisesti Pohjoismaiden ministerineuvoston yhteistyöalueiden painopisteitä vuonna 2015.

\section{Ministerineuvostojen poliittiset painopisteet}

Pääsihteeri sai vuonna 2013 tehtäväksi tarkastella pohjoismaisen hallitusyhteistyön tehostamis- ja parantamismahdollisuuksia. Toimeksiannon mukaisesti syksyllä 2013 ja keväällä 2014 laadittiin raportti Uusi Pohjola. Vuonna 2015 ministerineuvosto keskittyy toteuttamaan yhteistyöministerien vuonna 2014 hyväksymät suositukset, jotka koskevat ministeritason pohjoismaisen yhteistyön vahvistamista, sihteeristön toiminnan tehostamista, pohjoismaisen budjetin uudistamista, hanke- ja ohjelmatoiminnasta saatavan pohjoismaisen hyödyn lisäämistä sekä laitosohjauksen parantamista.

Ministeritason yhteistyötä voidaan vahvistaa muun muassa hyödyntämällä priorisointibudjettia, joka on ollut käytössä vuodesta 2013. Priorisointibudjetin tarkoituksena on mahdollistaa uusien suurten ja temaattisten kokonaispanostusten käynnistäminen.

Aiemmat puheenjohtajamaat Ruotsi ja Islanti jatkavat vuoden 2014 aloitteidensa toteuttamista priorisointibudjetin avulla. Lisäksi Tanska käynnistää priorisoituja panostuksia omalla puheenjohtajakaudellaan vuonna 2015.

Pääministerien priorisoimat aloitteet Vihreä kasvu ja Kestävä pohjoismainen hyvinvointi jatkuvat vuonna 2015. Vihreä kasvu -aloitteen tavoitteena on vahvistaa pohjoismaista yhteistyötä esimerkiksi energiatehokkuuden, uusiutuvan energian kehittämisen, ympäristötietoisuuden sekä ympäristö- ja ilmastoalan innovoinnin ja tutkimuksen saralla. Lisäksi aloite auttaa kasvattamaan alueellisia markkinoita ja luomaan kehitystyön edellyttämää kriittistä massaa.

Kestävä pohjoismainen hyvinvointi taas auttaa vahvistamaan pohjoismaista yhteistyötä, joka liittyy koulutukseen, työmarkkinoihin sekä tutkimukseen ja infrastruktuuriin hyvinvoinnin näkökulmasta. Ohjelmalla edistetään sitä, että koulutus johtaa Pohjoismaissa työllistymiseen, että 


\section{Keskustelut Pohjoismaiden neuvoston kanssa vuoden 2015 budjetista}

terveys- ja hoivaosaamisen tarjonta vastaa kysyntää ja että terveydenhuolto on laadukasta.

Vihreä kasvu- ja Kestävä pohjoismainen hyvinvointi -panostusten rinnalla toteutetaan sektorienvälistä pohjoismaista kestävän kehityksen strategiaa Hyvä elämä kestävässä Pohjolassa. Strategialla varmistetaan se, että Pohjoismaiden ministerineuvoston kaikkeen toimintaan sisältyy kestävyysnäkökulma.

Pohjoismaiden ministerineuvoston priorisointibudjetin avulla priorisoidaan vuonna 2015 myös terveysalan pohjoismaista yhteistyötä. Tämä tapahtuu osoittamalla määrärahoja seurantaan, joka liittyy Ruotsin entisen sosiaaliturvaministerin Bo Könbergin raporttiin terveysalan pohjoismaisen yhteistyön suuresta potentiaalista.

Pohjoismaiden ministerineuvosto priorisoi niin ikään työtä, jossa helpotetaan ihmisten ja yritysten rajat ylittävää toimintaa. Tämä tapahtuu muun muassa varmistamalla maiden välinen koordinointi ja yhteistyö, joka keskittyy kansallisiin lainsäädäntöprosesseihin sekä EU-säädösten täytäntöönpanoon.

Pohjoismaiden ministerineuvoston vuoden 2015 kansainvälinen yhteistyö keskittyy yhteistyösuhteiden kehittämiseen naapurimaiden ja muiden toimijoiden kanssa. Tässä yhteydessä on korostettava etenkin Pohjoismaiden ja pohjoismaisen yhteistyön kansainvälistä brändäyspanostusta. Se on vuonna 2015 tärkeä kehittämisalue, jossa piilee suuria mahdollisuuksia.
Syksyn 2014 aikana Pohjoismaiden neuvoston ja Pohjoismaiden ministerineuvoston välillä käytiin poliittisia neuvotteluja ministerineuvoston budjettiehdotuksesta. Neuvotteluissa päädyttiin seuraaviin muutoksiin ja tarkennuksiin vuoden 2015 budjetin osalta:

että Pohjoismaiden neuvosto osallistetaan budjettiuudistuksen jälkeen budjettiprosessiin entistä varhaisemmassa vaiheessa.

että ruokahävikin vähentäminen on edelleen yksi Pohjoismaiden ministerineuvoston prioriteeteista. Tarkoitusta varten varataan 2,4 miljoonaa Tanskan kruunua, josta 400000 kruunua sisältyy budjettikohtaan 1-8007 (biotalous) tietouden ja innovatiivisten ratkaisujen saavuttamiseksi ruokahävikin vähentämistyössä.

että arktinen yhteistyö on edelleen priorisoitu osa-alue ja että vuonna 2015 tarkoitukseen varattua budjettia korotetaan huomioiden, että yksi Tanskan puheenjohtajakauden painopistealueista on "Sininen Arktis".

että Uusi pohjoismainen ruoka -ohjelma viedään uuteen vaiheeseen kohdistamalla 894000 Tanskan kruunua keskeisten laitosten verkostojen vahvistamiseen strategisella tasolla. Lisäksi Tanskan puheenjohtajakaudella keskitytään muun muassa Uuteen pohjoismaiseen ruokaan ohjelman Arvot-osion puitteissa (budjettikohta 1-8010).

että budjettikohdassa 5-6610 tuodaan esiin, että kalastusyhteistyössä keskitytään jatkossakin rannikkoyhteisöjen kehitykseen, arktiseen alueeseen ja haasteisiin, jotka liittyvät muutoksiin kaupallisten lajien levinneisyydessä sisältäen Pohjois-Atlantin pelagiset lajit. Lisäksi Tanskan puheenjohtajakaudella keskitytään muun muassa kestävyyden lisäämiseen Pohjois-Atlantin luonnonvaroja hyödyntäessä ohjelman Kasvu-osion alla. 
että panostus biotalouteen on tärkeä osa työtä vihreän talouskasvun ja kestävyyden edistämiseksi. Biotalouden alalla tähän pyritään optimoimalla arvoketjun jätteen ja ympäristökuormituksen vähentämistä ja maksimoimalla arvoketjun arvoa. Tavoitteena on myös saada uudet sukupolvet ymmärtämään vihreän kasvun ja kestävyyden tärkeys sekä huomioimaan ruokaturva ja ilmastonmuutos.

että biologisen monimuotoisuuden hyväksi tehdyn työn tavoitteita budjettikohdassa 8-3311 (ympäristösektorin työryhmät) selvennetään seuraavasti:

- että Pohjoismaiden maaekosysteemien ekologinen tila on hyvä

- että ekosysteemien suojelun ja luonnon-, kulttuuri- ja kaupunkiympäristöjen kestävän käytön välinen hyvä tasapaino on voimavara, joka osaltaan edistää Pohjoismaiden väestön hyvinvointia, viihtyvyyttä ja ulkoilumahdollisuuksia

- että työllä pyritään edistämään, että sekä YK:n ilmastosopimus että yleissopimus biologisesta monimuotoisuudesta saavuttaa niille asetetut tavoitteet.

että Pohjoismaiden neuvostoa tiedotetaan kahdenvälisistä prosesseista maiden välillä ratkaisujen löytämiseksi panttikysymykseen ja että Pohjoismaiden ministerineuvosto muutoin odottaa prosessin tuloksia.

että Pohjoismaiden ministerineuvosto toteuttaa meriryhmän (HAV) ja NEFCOn kautta hankkeita Itämeren ympäristön tilan parantamiseksi ja varaa lisäksi 400000 Tanskan kruunua HELCOMille Itämeren suojelun toimintasuunnitelman (BSAP) toteuttamiseen. Panostukset kattavat laajan kentän ja niihin kuuluu esimerkiksi analyyseja, innovatiivisten ratkaisujen toteuttamista, seminaareja ja kehityshankkeita.

että Pohjoismaiden neuvoston palkintojenjakotilaisuuden toteuttamiseen varataan 400000 Tanskan kruunua. että Pohjoismaisen lehtimieskeskuksen toimintaan varataan 1 miljoona Tanskan kruunua vuonna 2015. Varat otetaan strategisista panostuksista (budjettikohta 4-2208).

että kunnes toisin päätetään, Pohjoismaisen kesäyliopiston (NSU) on voitava jatkaa toimintaansa nykyisellä tasolla ja että NordForsk voi vuonna 2015 vähentää NSU:lle myönnettäviä varoja enintään sen oman säästötavoitteen verran eli 2,4 prosenttia.

että käynnistetään selvitys siitä, saavutettaisiinko yhteisellä pohjoismaisella kirjastohankkeella synergiaa ja taloudellisia etuja.

että lapset ja nuoret ovat erityinen painopistealue Pohjoismaiden ministerineuvoston myöntäessä tukea elokuva- ja televisiotuotantoon Pohjoismaisen elokuva- ja televisiorahaston kautta.

että varataan vuoden 2015 budjetista määrärahoja Bo Könbergin tulevaisuuden pohjoismaista terveysyhteistyötä koskevan raportin suositusten toteuttamiseen mukaan lukien kasvavan mikrobilääkeresistenssin ehkäisyn. Lisäksi järjestetään vuosittainen Yksi terveys -kokous (mikrobilääkeresistenssi ihmisissä ja eläimissä).

että selvitetään, mitä voidaan tehdä Pohjoismaisten lasten ja yksinhuoltajien parissa esiintyvän köyhyyden ehkäisemiseksi.

että viime vuosien hyvien kokemusten pohjalta valmistellaan entisessä laajuudessaan uusi monialainen ohjelma sekä uusi panostus ihmiskaupan torjumiseksi.

että Pohjoismaiden ministerineuvosto arvioi kuluttajakonferenssin päätelmiä niiden valmistuttua ja selvittää mahdollisuuksia jatkaa työtä myrkyttömään arkeen liittyen. 


\section{Budjetin tulot ja maiden maksuosuudet}

Pohjoismaiden ministerineuvoston budjetti rahoitetaan ensisijaisesti maiden suorilla maksuilla. Maat maksavat lähtökohtaisesti summan, joka vastaa toimintakehystä ilman palkoista pidätettävää maksua, nettokorkotuottoja ja muita tuloja, jotka on eritelty alla olevassa taulukossa.
Maiden maksut määräytyvät erityisen jakoperusteen mukaan. Se perustuu kunkin maan osuuteen Pohjoismaiden yhteenlasketusta bruttokansantulosta tuotantokustannushinnoin kahden viimeisimmän tiedossa olevan vuoden, eli vuoden 2015 budjetissa vuosien 2011-2012 ajalta.

\begin{tabular}{|c|c|c|c|c|c|c|}
\hline $\begin{array}{l}\text { TULOT } \\
\text { Tuhatta Tanskan kruunua } \\
\text { (käyvin hinnoin) }\end{array}$ & $\begin{array}{r}\text { BUDJETTI } \\
2013\end{array}$ & $\begin{array}{r}\text { JAKOPERUSTE } \\
2013\end{array}$ & $\begin{array}{r}\text { BUDJETTI } \\
2014\end{array}$ & $\begin{array}{r}\text { JAKOPERUSTE } \\
2014\end{array}$ & $\begin{array}{r}\text { BUDJETTI } \\
2015\end{array}$ & $\begin{array}{r}\text { JAKOPERUSTE } \\
2015\end{array}$ \\
\hline Palkkaverot & 11000 & & 12000 & & 13000 & \\
\hline Muut tulot (esim. vuokrat) & 1200 & & 1100 & & 600 & \\
\hline Maiden maksuosuudet & 974526 & & 942115 & & 918182 & \\
\hline - Tanska & 217319 & $22,3 \%$ & 197844 & $21,0 \%$ & 183636 & $20,0 \%$ \\
\hline - Suomi & 169568 & $17,4 \%$ & 153565 & $16,3 \%$ & 142318 & $15,5 \%$ \\
\hline - Islanti & 6822 & $0,7 \%$ & 6595 & $0,7 \%$ & 6427 & $0,7 \%$ \\
\hline - Norja & 285536 & $29,3 \%$ & 288287 & $30,6 \%$ & 289227 & $31,5 \%$ \\
\hline - Ruotsi & 295281 & $30,3 \%$ & 295824 & $31,4 \%$ & 296573 & $32,3 \%$ \\
\hline YHTEENSÄ: & 986726 & $100 \%$ & 955215 & $100 \%$ & 931782 & $100 \%$ \\
\hline
\end{tabular}




\section{Maiden ennustetut maksuosuudet kansallisina valuuttoina}

Korkeampaan koulutukseen pääsyä koskevassa sopimuksessa on sovittu, että Pohjoismaiden maksujärjestelyä säädellään ministerineuvoston budjetista, jolloin se vaikuttaa maiden maksuosuuksiin. Maksujärjestely koskee Norjaa, Ruotsia, Suomea ja Tanskaa. Järjestelyn ulkopuolella ovat Ahvenanmaa, Färsaaret, Grönlanti ja Islanti.

Laskennassa ei oteta huomioon tutkijankoulutuksessa olevia opiskelijoita eikä erittelemättömässä korkea-asteen koulutuksessa opiskelevia. Vuosittainen opiskelijakohtainen korvaus oli 26000 Tanskan kruunua vuonna 2013 ja 30000 Tanskan kruunua vuonna 2014. Vuonna 2015 korvaus on 30304 Tanskan kruunua.

Ministerineuvosto vastaanottaa laskennan pohjaksi Pohjoismaiden opintotukiviranomaisilta vuosittain tilastotiedot järjestelmään sisältyvien opiskelijoiden määristä.
Seuraavasta taulukosta ilmenevät maiden maksut Pohjoismaiden ministerineuvostolle kansallisina valuuttoina ja tuhansina ilmaistuna. Lukuja on korjattu korkea-asteen koulutuksen maksujärjestelyn mukaisesti, ja lähtökohtana ovat yhteistyöministerien hyväksymät budjettivaluuttakurssit (ks. liite 2).

BUDJETTI 2015 - MAIDEN ENNAKOIDUT MAKSUOSUUDET KANSALLISINA VALUUTTOINA

\begin{tabular}{lrll|}
\hline Tanska & 98 & 179 & DKK \\
\hline Suomi & 22 & 347 & EUR \\
\hline Islanti & 136 & 751 & ISK \\
\hline Norja & 387 & 426 & NOK \\
\hline Ruotsi & 359 & 261 & SEK \\
\hline
\end{tabular}

\begin{tabular}{|c|c|c|c|}
\hline \multicolumn{4}{|c|}{$\begin{array}{l}\text { Korkea-asteen koulutuksen maksujärjestely, } \\
\text { tuhatta Tanskan kruunua }\end{array}$} \\
\hline & $\begin{array}{r}\text { BUDJETTI } \\
2013\end{array}$ & $\begin{array}{r}\text { BUDJETI } \\
2014\end{array}$ & $\begin{array}{r}\text { BUDJETTI } \\
2015\end{array}$ \\
\hline Tanska & -76830 & $\begin{array}{lll}-89 & 078\end{array}$ & $\begin{array}{lll}-85 & 457\end{array}$ \\
\hline Suomi & 17335 & 19777 & 24387 \\
\hline Islanti & 0 & 0 & 0 \\
\hline Norja & 46917 & 58343 & 59456 \\
\hline Ruotsi & 12578 & 10958 & 1614 \\
\hline YHTEENSÄ & 0 & 0 & 0 \\
\hline
\end{tabular}




\section{Budjetin kehitys vuosina 2004-2015}

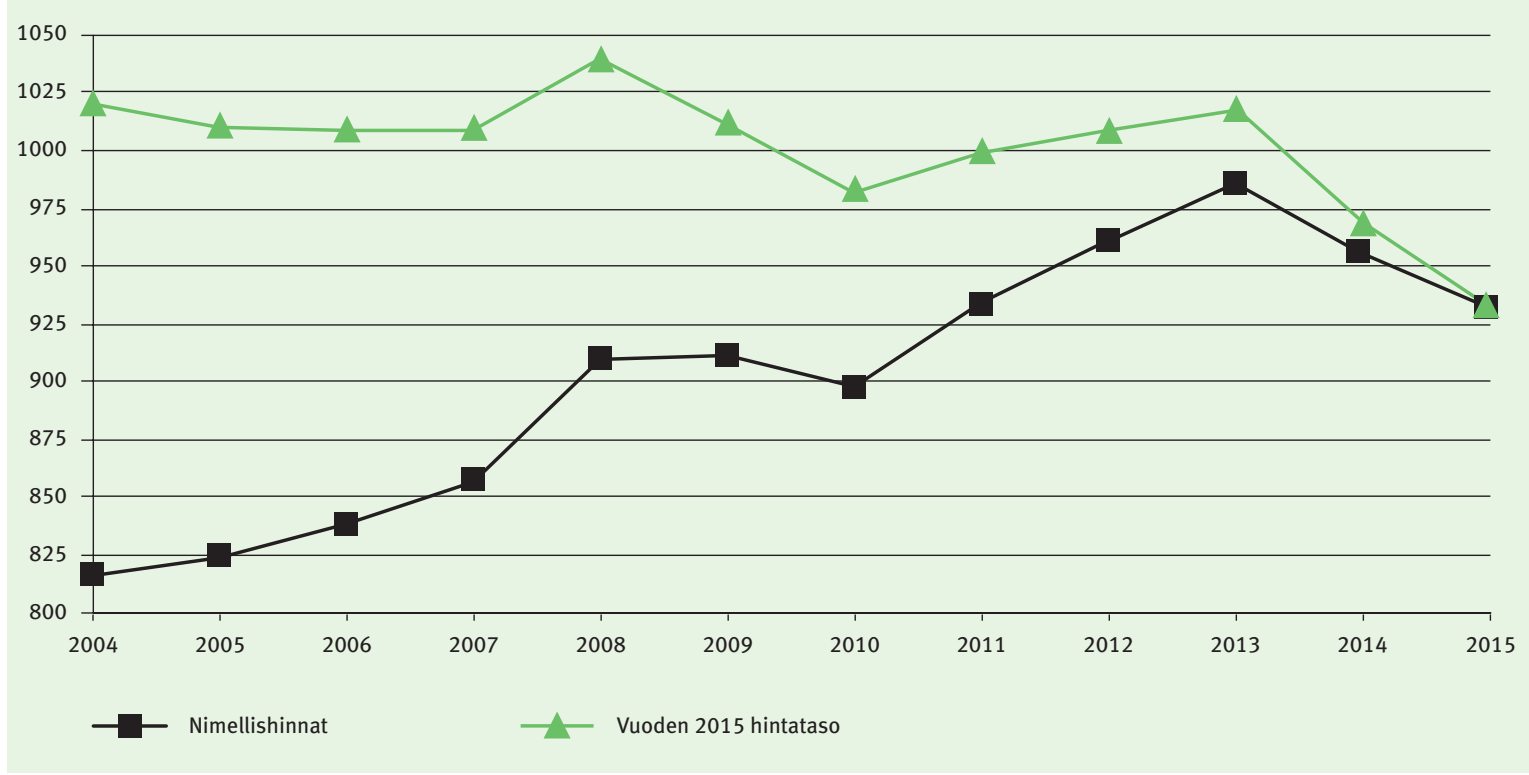

Pohjoismaiset yhteistyöministerit (MR-SAM) on hyväksynyt vuodeksi 2015 kehyksen, jota on leikattu $2 \%$ (19 miljoonaa Tanskan kruunua) vuoteen 2014 verrattuna. Vuodeksi 2014 kehystä leikattiin 5 \% vuoteen 2013 verrattuna (49 miljoonaa Tanskan kruunua).

Vuoden 2008 tasonmuutos johtui budjettivalmistelun yhteydessä tehdystä päätöksestä, jonka mukaan osa vuoden 2008 yhteensä 60 miljoonan Tanskan kruunun globalisaatioaloitteista - jotka pääministerit olivat julkistaneet Punkaharjulla kesäkuussa 2007 - rahoitettaisiin kasvattamalla toimintakehystä 35 miljoonaa Tanskan kruunua.

Valuuttakurssien heilahtelu selittää sen, miksi kiintein hinnoin ilmaistu vuoden 2010 budjetti on vuoden 2009 budjettia pienempi ja miksi vuoden 2011 budjettikin jää vuoden 2009 tasosta. Käytännössä kyse on Norjan ja
Ruotsin kruunujen suuresta arvonlaskusta Tanskan kruunuun nähden. Lasku alkoi vuoden 2008 jälkipuoliskolla ja päättyi vuoden 2009 puolivälissä. Vuosien 2011-2012 ja 2013 nousu johtuu vastaavasti Norjan ja Ruotsin kruunujen kallistumisesta Tanskan kruunuun nähden. Kiinteiden hintojen suhteellisen suuri lasku vuoden 2014 tasosta vuoden 2015 tasoon johtuu paitsi $2 \%$ :n budjettileikkauksesta myös Ruotsin ja Norjan kruunun arvon heikkenemisestä suhteessa Tanskan kruunuun. 


\section{Katsaus: Pohjoismaiden ministerineuvoston budjetti budjettikohdittain}

\begin{tabular}{|c|c|c|c|}
\hline \multicolumn{2}{|c|}{ TUHATTA TANSKAN KRUUNUA } & $\begin{array}{r}\text { BUDJETTI } \\
2015\end{array}$ & $\begin{array}{r}\text { BUDJETTI } \\
2014\end{array}$ \\
\hline \multicolumn{4}{|c|}{ Yhteistyöministerit (MR-SAM) } \\
\hline Priorisoi & udjetti yhteensä & 74375 & 74768 \\
\hline & Puheenjohtajamaan erä & 45676 & 30480 \\
\hline $1-8001$ & NordMin & 10150 & 10160 \\
\hline $1-8003$ & Lyhytikäisten ilmastoon vaikuttavien yhdisteiden päästöinventaarioiden parantaminen & 2030 & 2032 \\
\hline $1-8004$ & Työssäoppiminen & 3045 & 3048 \\
\hline 1-8005 & Pohjoismainen soittolista & 2030 & 2032 \\
\hline $1-8006$ & Hyvinvointivahti & 3045 & 3048 \\
\hline $1-8007$ & Biotalousaloite & 10150 & 10160 \\
\hline $1-8008$ & Kasvu & 4060 & 0 \\
\hline $1-8009$ & Hyvinvointi & 4060 & 0 \\
\hline $1-8010$ & Arvot & 4568 & 0 \\
\hline \multirow[t]{2}{*}{$1-8011$} & Sininen Arktis & 2538 & 0 \\
\hline & Priorisointierä & 28699 & 44288 \\
\hline $1-8110$ & Testikeskukset & 0 & 828 \\
\hline $1-8111$ & Vihreää kasvua edistävä koulutus ja tutkimus & 4060 & 3759 \\
\hline 1-8112 & Sähkömarkkinat & 1015 & 1173 \\
\hline $1-8113$ & Vihreät tekniset normit ja standardit - Pohjoismaat suunnannäyttäjinä & 2639 & 3251 \\
\hline $1-8114$ & Vihreät julkiset hankinnat & 0 & 2540 \\
\hline $1-8115$ & Jätehuollon tekniikoiden ja menetelmien kehittäminen & 4568 & 6736 \\
\hline $1-8116$ & Ympäristö- ja ilmastoasioiden valtavirtaistaminen kehitysyhteistyössä & 508 & 508 \\
\hline $1-8118$ & Vihreän kasvun erityispanostukset & 406 & 499 \\
\hline $1-8210$ & Kestävä pohjoismainen hyvinvointi & 11165 & 13208 \\
\hline $1-8212$ & Hyvinvointi ja ravitsemus & 785 & 1016 \\
\hline $1-8310$ & Ilmastoa säästävä rakentaminen & 0 & 5690 \\
\hline $1-8311$ & Kulttuuri ja luovuus - KreaNord-aloite & 0 & 4064 \\
\hline 1-8312 & Julkisen ja yksityisen sektorin kumppanuus kasvinjalostusalalla Pohjoismaissa & 0 & 508 \\
\hline $1-8313$ & Uusi pohjoismainen ruoka & 0 & 508 \\
\hline $1-8410$ & Poliittiset priorisoinnit & 3553 & 0 \\
\hline
\end{tabular}




\section{Yhteistyöministerit (MR-SAM)}

Kansainvälinen yhteistyö yhteensä

74320

1-0960 Itämeren alueen kansalaisjärjestötoiminta

\section{Yhteistyöministerit (MR-SAM)}

Yhteiset toiminnot ja sihteeristö yhteensä

1-0425 Länsi-Pohjola-tuki 


\begin{tabular}{|c|c|c|c|}
\hline \multicolumn{2}{|c|}{ TUHATTA TANSKAN KRUUNUA } & $\begin{array}{r}\text { BUDJETTI } \\
2015\end{array}$ & $\begin{array}{r}\text { BUDJETTI } \\
2014\end{array}$ \\
\hline Koulutu & tutkimusministerineuvosto (MR-U) & 228116 & 238384 \\
\hline & Yleiset koulutus- ja tutkimuspanostukset & 3680 & 2939 \\
\hline \multirow[t]{2}{*}{$2-2505$} & Käyttövarat - koulutus ja tutkimus & 3680 & 2939 \\
\hline & Politiikan kehittäminen ym. & 15481 & 17847 \\
\hline $2-2560$ & Painopistealueiden tilapäistyöryhmät & 0 & 2595 \\
\hline 2-2544 & Pohjoismainen kieliyhteistyö & 7015 & 6911 \\
\hline $2-2553$ & Politiikan kehittäminen, tietoyhteiskunta ja IT-infrastruktuuri & 568 & 560 \\
\hline \multirow[t]{2}{*}{$2-3127$} & Politiikan kehittäminen - aikuisten oppiminen & 7898 & 7781 \\
\hline & Liikkuvuus- ja verkosto-ohjelmat & 75735 & 74616 \\
\hline \multirow[t]{2}{*}{$2-2513$} & Nordplus & 75735 & 74616 \\
\hline & NordForsk & 111296 & 121382 \\
\hline \multirow[t]{2}{*}{$2-3100$} & NordForsk & 111296 & 121382 \\
\hline & Muu tutkimus & 21924 & 21600 \\
\hline $2-3180$ & Teoreettisen fysiikan pohjoismainen laitos (NORDITA) & 9002 & 8869 \\
\hline 2-3181 & Pohjoismainen merioikeuden laitos (NifS) & 2683 & 2643 \\
\hline 2-3182 & Pohjoismainen Aasian-tutkimusinstituutti (NIAS) & 4253 & 4190 \\
\hline $2-3184$ & Pohjoismainen vulkanologinen instituutti (NORDVULK) & 4344 & 4280 \\
\hline 2-3185 & Pohjoismainen saamelaisinstituutti (NSI) & 1642 & 1618 \\
\hline
\end{tabular}

Sosiaali- ja terveyspolitiikan ministerineuvosto (MR-S)

\section{Hankevarat}

3-4310 Hankevarat - sosiaali- ja terveyspolitiikka sosiaalitilastokomitea (NOSOSKO)

3-4382 Pohjoismainen hammasmateriaalin koestuslaitos (NIOM AS)

3-4381 Nordic School of Public Health (NHV)*

*NHV saa rahoituksensa suoraan jäsenmailta, joten sitä ei ole sisällytetty kokonaissummaan. 


\begin{tabular}{|c|c|c|c|}
\hline \multicolumn{2}{|c|}{ TUHATTA TANSKAN KRUUNUA } & $\begin{array}{r}\text { BUDJETTI } \\
2015\end{array}$ & $\begin{array}{r}\text { BUDJETTI } \\
2014\end{array}$ \\
\hline \multicolumn{2}{|c|}{ Kulttuuriministerineuvosto (MR-K) } & 167143 & 167879 \\
\hline & Yleiset kulttuuripanostukset & 46284 & 46416 \\
\hline 4-2203 & Käyttövarat - kulttuuri & 941 & 1028 \\
\hline 4-2205 & Pohjoismainen kulttuurirahasto & 34342 & 34525 \\
\hline 4-2206 & Pohjoismaiden neuvoston palkinnot & 3583 & 3530 \\
\hline \multirow[t]{3}{*}{ 4-2208 } & Strategiset panostukset & 7418 & 7333 \\
\hline & Lapset ja nuoret & 6036 & 6068 \\
\hline & Hankevarat ja yleiset tukijärjestelmät & 6036 & 6068 \\
\hline \multirow[t]{3}{*}{ 4-2212 } & Pohjoismainen lapsi- ja nuorisoyhteistyön komitea (NORDBUK) & 6036 & 6068 \\
\hline & Elokuva ja viestimet & 35062 & 37207 \\
\hline & Hankevarat ja yleiset tukijärjestelmät & 32037 & 34063 \\
\hline 4-2221 & Pohjoismainen tietokonepeliohjelma & 4172 & 6610 \\
\hline \multirow[t]{2}{*}{ 4-2222 } & Pohjoismainen elokuva- ja televisiorahasto & 27865 & 27453 \\
\hline & Laitokset & 3025 & 3144 \\
\hline \multirow[t]{3}{*}{ 4-2228 } & Viestintätutkimuksen pohjoismainen dokumentointikeskus (NORDICOM) & 3025 & 3144 \\
\hline & Taideala & 76003 & 74486 \\
\hline & Hankevarat ja yleiset tukijärjestelmät & 33210 & 32719 \\
\hline 4-2251 & Kulttuuri- ja taideohjelma & 17786 & 17523 \\
\hline 4-2253 & Pohjoismainen käännöstuki & 3067 & 3022 \\
\hline \multirow[t]{2}{*}{ 4-2254 } & Pohjoismaiden ja Baltian maiden kulttuurialan liikkuvuusohjelma & 12357 & 12174 \\
\hline & Pohjoismaiset kulttuuritalot (laitokset) & 42793 & 41767 \\
\hline $4-2270$ & Reykjavikin Pohjolan-talo (NOREY) & 8887 & 8412 \\
\hline 4-2272 & Färsaarten Pohjolan-talo (NHFØ) & 13490 & 13330 \\
\hline 4-2274 & Ahvenanmaan Pohjola-instituutti (NIPÅ) & 2944 & 2895 \\
\hline $4-2277$ & Grönlannin Pohjola-instituutti (NAPA) & 6322 & 6247 \\
\hline \multirow[t]{3}{*}{ 4-2548 } & Pohjoismainen kulttuuripiste (KKN) & 11150 & 10883 \\
\hline & Muut kulttuuripanostukset & 3758 & 3702 \\
\hline & Hankevarat ja yleiset tukijärjestelmät & 3758 & 3702 \\
\hline 4-2234 & Saamelaisyhteistyö & 3758 & 3702 \\
\hline
\end{tabular}




\begin{tabular}{|c|c|c|c|}
\hline \multicolumn{2}{|c|}{ TUHATTA TANSKAN KRUUNUA } & BUDJETTI & BUDJETTI \\
\hline \multicolumn{2}{|c|}{ Maa- ja metsätalous-, kalastus-, vesiviljely- ja elintarvikeasiain ministerineuvosto (MR-FJLS) } & 39769 & 41093 \\
\hline & Hankevarat & 907 & 1716 \\
\hline \multirow[t]{2}{*}{$5-6420$} & Uusi pohjoismainen ruoka & 907 & 1716 \\
\hline & Kalastus & 6198 & 6106 \\
\hline \multirow[t]{3}{*}{$5-6610$} & Hankevarat - kalastus & 6198 & 6106 \\
\hline & Maa- ja metsätalous & 27071 & 27761 \\
\hline & Hankevarat-maatalous & 1188 & 1171 \\
\hline $5-6510$ & Hankevarat - maatalous & 369 & 364 \\
\hline \multirow[t]{2}{*}{$5-6520$} & Maataloustutkimuksen pohjoismainen kontaktielin (NKJ) & 819 & 807 \\
\hline & Laitokset - maatalous & 20016 & 20810 \\
\hline \multirow[t]{2}{*}{$5-6585$} & Pohjoismainen geenivarakeskus (NordGen) & 20016 & 20810 \\
\hline & Hankevarat-metsätalous & 5867 & 5780 \\
\hline $5-6310$ & Hankevarat - metsätalous & 306 & 301 \\
\hline \multirow[t]{2}{*}{$5-6581$} & Yhteispohjoismainen metsäntutkimus (SNS) & 5561 & 5479 \\
\hline & Elintarvikkeet & 5593 & 5510 \\
\hline $5-6810$ & Hankevarat - elintarvikkeet & 5046 & 4971 \\
\hline $5-6830$ & Pohjoismainen toimintasuunnitelma terveyden ja elämänlaadun parantamiseksi & 547 & 539 \\
\hline
\end{tabular}

\begin{tabular}{|c|c|c|c|}
\hline \multicolumn{2}{|c|}{ TUHATTA TANSKAN KRUUNUA } & $\begin{array}{r}\text { BUDJETTI } \\
2015\end{array}$ & $\begin{array}{r}\text { BUDJETTI } \\
2014\end{array}$ \\
\hline \multicolumn{2}{|c|}{ Tasa-arvoasiain ministerineuvosto (MR-JÄM) } & 8873 & 8919 \\
\hline & Hankevarat & 8873 & 8919 \\
\hline $6-4410$ & Hankevarat - tasa-arvo & 3493 & 6379 \\
\hline 6-4420 & MR-JÄMin tukijärjestelmä & 2842 & 0 \\
\hline $6-4480$ & Pohjoismainen tasa-arvotiedon keskus (NIKK) & 2538 & 2540 \\
\hline
\end{tabular}




\begin{tabular}{|c|c|c|c|}
\hline \multicolumn{2}{|c|}{ TUHATTA TANSKAN KRUUNUA } & $\begin{array}{r}\text { BUDJETTI } \\
2015\end{array}$ & $\begin{array}{r}\text { BUDJETTI } \\
2014\end{array}$ \\
\hline \multicolumn{2}{|c|}{ Elinkeino-, energia- ja aluepolitiikan ministerineuvosto (MR-NER) } & 132686 & 140438 \\
\hline & Elinkeinopolitiikka & 89619 & 95991 \\
\hline 7-5140 & Hankevarat - elinkeinopolitiikka & 1986 & 1957 \\
\hline \multirow[t]{2}{*}{ 7-5280 } & Pohjoismaiden projektivientirahasto (NOPEF) & 15162 & 14938 \\
\hline & Laitokset-elinkeinopolitiikka & 72471 & 79096 \\
\hline \multirow[t]{2}{*}{ 7-5180 } & Nordic Innovation & 72471 & 79096 \\
\hline & Energia & 10582 & 11163 \\
\hline \multirow[t]{2}{*}{ 7-5141 } & Hankevarat - energiapolitiikka & 4130 & 4192 \\
\hline & Laitokset - energiapolitiikka & & 6971 \\
\hline \multirow[t]{2}{*}{ 7-3220 } & Pohjoismainen energiantutkimus (NEF) & 6452 & 6971 \\
\hline & Aluepolitiikka & 32485 & 33284 \\
\hline 7-5143 & Hankevarat - aluepolitiikka & 5320 & 5393 \\
\hline 7-5151 & Pohjoismainen Atlantti-yhteistyö (NORA) & 6624 & 6640 \\
\hline \multirow[t]{2}{*}{ 7-5160 } & Raja-alueyhteistyö & 9287 & 9550 \\
\hline & Laitokset-aluepolitiikka & 11254 & 11701 \\
\hline 7-6180 & Pohjoismainen aluekehityksen keskus (Nordregio) & 11254 & 11701 \\
\hline
\end{tabular}




\begin{tabular}{|c|c|c|c|}
\hline \multicolumn{2}{|c|}{ TUHATTA TANSKAN KRUUNUA } & $\begin{array}{r}\text { BUDJETTI } \\
2015\end{array}$ & $\begin{array}{r}\text { BUDJETTI } \\
2014 \\
\end{array}$ \\
\hline \multicolumn{2}{|c|}{ Työelämän ministerineuvosto (MR-A) } & 13632 & 13698 \\
\hline & Hankevarat & 10262 & 10384 \\
\hline $9-4110$ & Muut hankevarat - työelämä & 907 & 694 \\
\hline $9-4111$ & Pysyvät jaostot - työelämä & 4583 & 4989 \\
\hline $9-4120$ & Nordjobb & 3160 & 3113 \\
\hline \multirow[t]{2}{*}{$9-4130$} & Työelämäviestintä & 1612 & 1588 \\
\hline & Laitokset & 3370 & 3314 \\
\hline $9-4180$ & Pohjoismainen työsuojelukoulutusinstituutti (NIVA) & 3370 & 3314 \\
\hline
\end{tabular}

TUHATTA TANSKAN KRUUNUA

Talous- ja rahapolitiikan ministerineuvosto (MR-FINANS)

10-5210 Hankevarat - talous- ja rahapolitiikka

\begin{tabular}{|rr|}
\hline BUDJETTI & BUDJETTI \\
2015 & 2014 \\
\hline 1810 & 1819 \\
\hline 1810 & 1819 \\
\hline
\end{tabular}

\begin{tabular}{|rr|}
\hline BUDJETTI & BUDJETTI \\
2015 & 2014 \\
\hline 1382 & 1390 \\
\hline 1382 & 1390 \\
\hline
\end{tabular}




\section{Liite 1:}

\section{Pohjoismaisten laitosten määrärahat kansallisina valuuttoina}

\begin{tabular}{|c|c|c|c|c|c|c|c|c|}
\hline \multicolumn{3}{|c|}{ POHJOISMAISTEN LAITOSTEN MÄÄRÄRAHAT } & \multicolumn{2}{|r|}{2015} & \multicolumn{4}{|c|}{2014} \\
\hline \multicolumn{9}{|c|}{ Koulutus- ja tutkimusministerineuvosto (MR-U) } \\
\hline $2-3100$ & NordForsk & 123 & 662 & 000 & 123 & 859 & 000 & NOK \\
\hline \multicolumn{9}{|c|}{ Maa- ja metsätalous-, kalastus-, vesiviljely- ja elintarvikeasiain ministerineuvosto (MR-FJLS) } \\
\hline $5-6585$ & Pohjoismainen geenivarakeskus (NordGen) & 24 & 116 & 000 & 23 & 920 & 000 & SEK \\
\hline \multicolumn{9}{|c|}{ Kulttuuriministerineuvosto (MR-K) } \\
\hline 4-2228 & Viestintätutkimuksen pohjoismainen dokumentointikeskus (NORDICOM) & 3 & 644 & 000 & 3 & 614 & 000 & SEK \\
\hline 4-2270 & Reykjavikin Pohjolan-talo (NOREY) & 189 & 088 & 000 & 182 & 870 & 000 & ISK \\
\hline 4-2272 & Färsaarten Pohjolan-talo (NHFØ) & 13 & 490 & 000 & 13 & 330 & 000 & DKK \\
\hline 4-2274 & Ahvenanmaan Pohjola-instituutti (NIPÅ) & & 394 & 700 & & 388 & 100 & EUR \\
\hline 4-2277 & Grönlannin Pohjola-instituutti (NAPA) & 6 & 322 & 000 & 6 & 247 & 000 & DKK \\
\hline 4-2548 & Pohjoismainen kulttuuripiste (KKN) & 1 & 494 & 600 & 1 & 458 & 800 & EUR \\
\hline \multicolumn{9}{|c|}{ Sosiaali- ja terveyspolitiikan ministerineuvosto (MR-S) } \\
\hline $3-4380$ & Pohjoismainen hyvinvointikeskus (NVC) & 24 & 500 & 000 & 24 & 301 & 000 & SEK \\
\hline 3-4381 & Nordic School of Public Health (NHV) & & & 0 & 45 & 989 & 000 & SEK \\
\hline \multicolumn{9}{|c|}{ Elinkeino-, energia- ja aluepolitiikan ministerineuvosto (MR-NER) } \\
\hline 7-5180 & Nordic Innovation & 80 & 523 & 000 & 80 & 710 & 000 & NOK \\
\hline 7-3220 & Pohjoismainen energiantutkimus (NEF) & 7 & 169 & 000 & 7 & 113 & 000 & NOK \\
\hline 7-6180 & Pohjoismainen aluekehityksen keskus (Nordregio) & 13 & 559 & 000 & 13 & 449 & 000 & SEK \\
\hline \multicolumn{9}{|c|}{ Työelämän ministerineuvosto (MR-A) } \\
\hline $9-4180$ & Pohjoismainen työsuojelukoulutusinstituutti (NIVA) & & 451 & 800 & & 444 & 200 & EUR \\
\hline
\end{tabular}


Liite 2:

Valuuttakurssit ja inflaatioprosentit 2015

\begin{tabular}{llrl}
\hline VALUUTTAKURSSIT JA INFLAATIOPROSENTIT & & \\
\hline 100 EUR & $=$ & 746 & DKK \\
\hline $100 \mathrm{ISK}$ & $=$ & 4,7 & DKK \\
\hline $100 \mathrm{NOK}$ & $=$ & 90 & DKK \\
\hline $100 \mathrm{SEK}$ & $=$ & 83 & DKK \\
\hline Tanska & & & $1,2 \%$ \\
\hline Suomi & & & $1,7 \%$ \\
\hline Islanti & & & $3,4 \%$ \\
\hline Norja & & & $2,25 \%$ \\
\hline Ruotsi & & & $0,82 \%$
\end{tabular}

Hankevarojen muuntokerroin on 1,5\%. 


$$
\int
$$



